\title{
The Prevalence and Determinant Factors of Oral Halitosis in Northwest Ethiopia: A Cross-Sectional Study
}

\section{Amare Teshome (iD) \\ Kirubel Derese \\ Getaneh Andualem (D)}

Department of Dentistry, School of Medicine, College of Medicine and Health Science, University of Gondar, Gondar, Ethiopia
Correspondence: Amare Teshome Department of Dentistry, School of Medicine, College of Medicine and Health Science, University of Gondar, Gondar, Ethiopia

Tel +25I-9105I7002

Email teferaden@gmail.com
Background: Oral halitosis, unpleasant or offensive odor to others, has become a major health concern among the general population, ranking the third most common reason for seeking a dentist behind dental caries and periodontal disease. Even though there have been repeated cases of halitosis in Ethiopia, there is no documented evidence.

Objective: The purpose of this study was to determine the prevalence of halitosis in Northwest Ethiopia and to examine the relationship between halitosis and sociodemographic factors, oral habits, and health practices.

Methods: From December 2019 to March 30, 2020, a hospital-based cross-sectional study was conducted. A systematic random sampling method was used to select study participants. Following informed consent, sociodemographic characteristics were collected using structured questionnaires, and two qualified dental surgeons performed the oral examination. The organoleptic test was used to assess the presence of halitosis.

Results: Six hundred sixty-one people took part in the study, with a mean age of $30.0 \pm 14.76$ years. The prevalence of oral halitosis was $44.2 \%$ (95\% CI: 40.39-47.96) among the study participants. Participants with no formal education were more prone to oral halitosis. Oral halitosis was common in students $(18.5 \%)$, low-income individuals $(22.2 \%)$, rural residents $(12.3 \%)$, mouth breathers $(19.1 \%)$, and participants with poor oral hygiene practices $(15.3 \%)$. Independent factors of halitosis included rural residency $(\mathrm{AOR}=1.40,95 \% \mathrm{CI}$ : $1.18,1.67)$, low economic status $(\mathrm{AOR}=1.81,95 \% \mathrm{CI}$ : 1.06,3.09), poor tooth brushing habit $(\mathrm{AOR}=1.85(1.31,2.61)$, smoking $(\mathrm{AOR}=2.69 \quad(1.39,5.21)$ and dental caries $(\mathrm{AOR}=8.74(5.57,13.71)$.

Conclusion: The prevalence of oral halitosis was $44.2 \%$ among the study participants. Rural residency, low monthly income, poor tooth-brushing habit, smoking, and dental caries were independent factors of halitosis.

Keywords: bad breath, oral halitosis, prevalence, oral malodor, Northwest Ethiopia

\section{Background}

Halitosis, also known as malodor, is a worldwide public health issue. ${ }^{1}$ It is a foul or offensive odor emitted from a person's mouth. ${ }^{2}$ The most common volatile molecules that cause halitosis are sulfur compounds, amines, nitrogen-containing compounds, alcohols, short-chain fatty acids, aliphatic compounds, and ketones are the common volatile compounds that cause halitosis. ${ }^{3,4}$ Etiologically halitosis is classified into physiologic (type 0), oral (type 1), airway (type 2), gastroesophageal (type 3), blood-born (type 4) and subjective (type 5). ${ }^{5,6}$ 
Halitosis is reported to be the third most common reason for visiting a dentist, trailing only dental caries and periodontal disease. ${ }^{7,8}$ The prevalence of halitosis among adults worldwide ranged from $22 \%$ to $50 \% .{ }^{9}$ Halitosis has a social impact on those who suffer from it, affecting their normal daily activities such as social and professional relationships, as well as communication..$^{10}$ Furthermore, it has an impact on an individual's confidence, self-esteem, reduces employment, and overall quality of life. ${ }^{10,11}$ The psychological effect of halitosis forced individuals to excessive use of chewing gums, mouthwashes, or medications to mask the odor and find a solution to this distressing problem. ${ }^{12}$

Halitosis has a multifactorial etiology, but the main factor is the decomposition of organic matter by proteolytic anaerobic bacteria. ${ }^{13}$ Poor oral hygiene, misaligned tooth, fault restoration, wound infection, smoking, alcohol, some foods, dry mouth, stress, obesity, periodontal disease, ill-fitting denture, and upper respiratory tract infections were the commonly reported causes of halitosis were the common causes. ${ }^{13,14}$ In the general population, $80-85 \%$ of halitosis cases were caused by intraoral factors, ${ }^{13,15}$ with the remaining $10 \%$ caused by upper respiratory tract infections. ${ }^{16,17}$

To date, there is a scarcity of data on the prevalence and associated factors of oral halitosis in Ethiopia. Therefore, this study aimed to determine the prevalence of oral halitosis and its associated factors in Northwest Ethiopia.

\section{Patients and Methods}

\section{Setting}

A hospital-based cross-sectional study was conducted at the University of Gondar Comprehensive specialized hospital dental clinic from December 1, 2019, to March 30, 2020. The hospital serves more than 7 million people in the catchment area. The dental clinic is one of the specialty centers in the University of Gondar comprehensive hospital, which has both outpatient and inpatient departments.

\section{Study Participants}

The source population included all patients who visited the University of Gondar comprehensive specialized hospital, while the study population included those who visited the dental clinic during the data collection period.

\section{Exclusion Criteria}

Participants who met the following criteria were excluded from the study.
- A patient with a dental emergency or who was critically ill

- A history of tooth extraction within a week

- Patients who refused to sign a consent form

- Pregnant women

- Participants fasted from the previous midnight until the time of evaluation

- Individuals with sore throat and sinusitis, neurological, psychiatric, or behavioral disorders

\section{Sampling Technique and Procedures}

The single population proportion formula was used to calculate the sample size. Assuming a prevalence of 50\% (no previous study in Ethiopia), a margin of error of $4 \%$, and a non-response rate of 10\%, the final sample size was 661 .

\section{Sampling Procedure}

A systematic random sampling method was employed to select the study subjects. The sampling interval $(\mathrm{K})$ was calculated by dividing the predicted number of participants per month by the sample size. A lottery method was used to determine the first study participant and every fourth patient was included in the study $(\mathrm{K}=4)$ until the desired sample size was achieved.

\section{Data Collection}

The questionnaire used in this study was adapted from previous studies. ${ }^{18-20}$ The questionnaire includes information about sociodemographic characteristics (such as sex, age, marital status, occupation, residency, and monthly income), oral hygiene practice, dietary habits, smoking history, and systemic disease. Moreover, the intraoral examination includes information about dentition status, periodontal condition, and occlusal relationship.

The study included questionnaire administration and clinical oral examination. Data on the self-administered questionnaire was collected in the waiting area of the dental clinic before the intraoral examination.

\section{Oral Examination/Organoleptic Test}

Two calibrated dentists performed the intraoral examination and organoleptic test. The magnitude of the odor was graded on a scale of 0 to 5 ( 0 : no odor, 1: barely noticeable, 2 : slight but noticeable, 3 : moderate, 4 : strong, and 5: extremely strong). ${ }^{21,22}$ To reduce the procedures, the two dentists did the organoleptic test at the same time; nevertheless, neither of them was aware of the other examiner the assessment. Participants with an organoleptic test score of $\geq 2$ were considered as having oral halitosis. $^{23-25}$ The organoleptic test was performed 2 hours 
after breakfast to avoid false results caused by fasting and certain diets that alter the odor of the oral cavity. ${ }^{26}$ There was a 5-minute break between each examination to standardize the clinical examination and avoid adaptation.

\section{Quality Assurance}

To ensure the study's quality, a pilot test was performed on 70 individuals who shared the same socio-demographic characteristics as the study's participants. Some amendments were made to the prepared questionnaire based on the results of the pilot test. For five days, data collectors were trained on research ethics, study objectives, data confidentiality, and consent.

\section{Data Analysis}

Data were cleaned, coded, and entered using the Epi-Info version 7. SPSS software (version 26) was used to analyze the data. Categorical variables were presented using frequencies and percentages. Binary logistic regression models were used to evaluate the presence of a statistical association between independent factors and halitosis. Study variables with a P-value of $\leq 0.2$ were entered into the multivariable model to control the possible confounders. The level of significance was set at $5 \%$.

\section{Ethical Consideration}

The Institutional Review Board (IRB) of the University of Gondar approved the study (V/P/RCS/05/149/2019). Written consent was obtained from each study participant, and written assent was taken from parents or legal guardians for under 18 years children. The authors tried to minimize the study participant's confidentiality by avoiding personal identifiers.

\section{Results}

\section{Sociodemographic Characteristics of the} Study Participants

Six hundred sixty-one participants were involved in the study with a response rate of $100 \%$. The mean age of the study participants was $30.0 \pm 14.766$ (SD) years with a median age

Table I The Prevalence of Halitosis According to the Socio-Demographic Characteristics of the Study Participants

\begin{tabular}{|c|c|c|c|c|c|}
\hline \multicolumn{2}{|c|}{ Socio-Demographic Characteristics } & \multicolumn{3}{|l|}{ Halitosis } & \multirow[t]{2}{*}{ P-value } \\
\hline & & Yes & No & Total & \\
\hline Sex & $\begin{array}{l}\text { Male } \\
\text { Female }\end{array}$ & $\begin{array}{l}143(21.6 \%) \\
149(22.5 \%)\end{array}$ & $\begin{array}{l}195(29.5 \%) \\
174(26.3 \%)\end{array}$ & $\begin{array}{l}338(51.1 \%) \\
323(48.9 \%)\end{array}$ & 0.347 \\
\hline Age & $\begin{array}{l}12-34 \\
35-49 \\
50-90\end{array}$ & $\begin{array}{l}208(31.5 \%) \\
50(7.6 \%) \\
34(5.1 \%)\end{array}$ & $\begin{array}{l}274(41.5 \%) \\
46(7.0 \%) \\
49(7.4 \%)\end{array}$ & $\begin{array}{l}482(72.9 \%) \\
96(14.5 \%) \\
83(12.6 \%)\end{array}$ & 0.2428 \\
\hline Marital status & $\begin{array}{l}\text { Single } \\
\text { Married } \\
\text { Divorced }\end{array}$ & $\begin{array}{l}137(20.7 \%) \\
149(22.5 \%) \\
6(0.9 \%)\end{array}$ & $\begin{array}{l}170(25.7 \%) \\
178(26.9 \%) \\
21(3.2 \%)\end{array}$ & $\begin{array}{l}307(46.4 \%) \\
327(49.5 \%) \\
27(4.1 \%)\end{array}$ & 0.64 \\
\hline Educational status & $\begin{array}{l}\text { Illiterate } \\
1-4 \\
5-8 \\
9-12 \\
\text { College/University }\end{array}$ & $\begin{array}{l}90(13.6 \%) \\
44(6.7 \%) \\
42(6.4 \%) \\
28(4.2 \%) \\
88(13.3 \%)\end{array}$ & $\begin{array}{l}53(8.0 \%) \\
54(8.2 \%) \\
54(8.2 \%) \\
49(7.4 \%) \\
159(24.1 \%)\end{array}$ & $\begin{array}{l}143(21.6 \%) \\
98(14.8 \%) \\
96(14.5 \%) \\
77(11.6 \%) \\
247(37.4 \%)\end{array}$ & 0.000 \\
\hline Occupation & $\begin{array}{l}\text { Farmer } \\
\text { Student } \\
\text { Governmental employee } \\
\text { NGO-employee } \\
\text { Merchant/personal bushiness }\end{array}$ & $\begin{array}{l}48(7.3 \%) \\
122(18.5 \%) \\
36(5.4 \%) \\
0(0.0 \%) \\
86(13.0 \%)\end{array}$ & $\begin{array}{l}50(7.6 \%) \\
112(16.9 \%) \\
83(12.6 \%) \\
15(2.3 \%) \\
109(16.5 \%)\end{array}$ & $\begin{array}{l}98(14.8 \%) \\
234(35.4 \%) \\
119(18.0 \%) \\
15(2.3 \%) \\
195(29.5 \%)\end{array}$ & 0.000 \\
\hline Residency & $\begin{array}{l}\text { Urban } \\
\text { Rural }\end{array}$ & $\begin{array}{l}211(31.9 \%) \\
81(12.3 \%)\end{array}$ & $\begin{array}{l}308(46.6 \%) \\
61(9.2 \%)\end{array}$ & $\begin{array}{l}519(78.5 \%) \\
142(21.5 \%)\end{array}$ & 0.001 \\
\hline Monthly income & $\begin{array}{l}<1000 \text { ETB } \\
1000-2500 \text { ETB } \\
\geq 2501 \text { ETB }\end{array}$ & $\begin{array}{l}147(22.2 \%) \\
92(13.9 \%) \\
53(8.0 \%)\end{array}$ & $\begin{array}{l}152(23.0 \%) \\
96(14.5 \%) \\
121(18.3 \%)\end{array}$ & $\begin{array}{l}299(45.2 \%) \\
188(28.4 \%) \\
174(26.3 \%)\end{array}$ & 0.000 \\
\hline
\end{tabular}


of 28.0. The majority of the study participants $(72.9 \%)$ were within $12-34$ years. More than $1 / 3^{\text {rd }}$ of the study participants attended college/university and $3 / 4^{\text {th }}$ of the study participants were urban residents (Table 1).

\section{The Prevalence of Halitosis Among the}

\section{Study Participants}

The prevalence of oral halitosis was $44.2 \%$ among the study participants (95\% CI: 40.39-0.4796). Halitosis was found in $1 / 3^{\text {rd }}(31.5 \%)$ of participants aged 12 to 34 years. The prevalence was relatively high in rural residents $(22.3 \%)$, and participants with low monthly income
$(22.2 \%)$ (Table 1). Furthermore, $55.2 \%$ of participants with poor tooth brushing habits had oral halitosis. Oral halitosis was common in mouth breathers (58.6\%), smokers $(66.7 \%)$, and patients with dental caries $(81.3 \%)$ (Table 2).

\section{Factors Associated with Halitosis Among the Study Participants}

Variables, which had a significant association in the bivariate analysis (age, educational status, occupation, residency, monthly income, tooth brushing habits, smoking, and dental caries), entered into the multivariate logistic regression

Table 2 Prevalence of Halitosis Among the Study Participant According to the Oral Health Practice, Oral Habits and Dietary Factors

\begin{tabular}{|c|c|c|c|c|c|}
\hline \multicolumn{2}{|l|}{ Risk Factors } & \multicolumn{2}{|l|}{ Halitosis } & \multirow{3}{*}{$\begin{array}{l}\text { Total } \\
478(72.3 \%) \\
183(27.7 \%)\end{array}$} & \multirow{3}{*}{$\begin{array}{l}\text { P-value } \\
0.000\end{array}$} \\
\hline & & \multirow{2}{*}{$\begin{array}{l}\text { Yes } \\
191(28.9 \%) \\
101(15.3 \%)\end{array}$} & \multirow{2}{*}{$\begin{array}{l}\text { No } \\
287(43.4 \%) \\
82(12.4 \%)\end{array}$} & & \\
\hline A habit of tooth brushing & $\begin{array}{l}\text { Yes } \\
\text { No }\end{array}$ & & & & \\
\hline Frequency of tooth brushing & $\begin{array}{l}\text { After every meal } \\
\text { Twice/day } \\
\text { Once/day } \\
\text { Some times }\end{array}$ & $\begin{array}{l}0(0.0 \%) \\
0(0.0 \%) \\
75(11.3 \%) \\
123(18.6 \%)\end{array}$ & $\begin{array}{l}7(1.1 \%) \\
34(5.1 \%) \\
63(9.5 \%) \\
183(27.7 \%)\end{array}$ & $\begin{array}{l}7(1.1 \%) \\
34(5.1 \%) \\
138(20.9 \%) \\
306(46.3 \%)\end{array}$ & 0.000 \\
\hline Timing of tooth brushing & $\begin{array}{l}\text { Before bed } \\
\text { Morning } \\
\text { Morning and before bed } \\
\text { No fixed time }\end{array}$ & $\begin{array}{l}0(0.0 \%) \\
83(12.6 \%) \\
14(2.1 \%) \\
88(13.3 \%)\end{array}$ & $\begin{array}{l}21(3.2 \%) \\
122(18.5 \%) \\
27(4.1 \%) \\
117(17.7 \%)\end{array}$ & $\begin{array}{l}21(3.2 \%) \\
205(31.0 \%) \\
41(6.2 \%) \\
205(31.0 \%)\end{array}$ & 0.000 \\
\hline Way of tooth brushing & $\begin{array}{l}\text { Horizontal stroke } \\
\text { Vertical stroke } \\
\text { Semi-circular } \\
\text { Gum to incisal edge }\end{array}$ & $\begin{array}{l}157(23.8 \%) \\
21(3.2 \%) \\
13(2.0 \%) \\
7(1.1 \%)\end{array}$ & $\begin{array}{l}232(35.1 \%) \\
35(5.3 \%) \\
14(2.1 \%) \\
0(0.0 \%)\end{array}$ & $\begin{array}{l}389(58.9 \%) \\
56(8.5 \%) \\
27(4.1 \%) \\
7(1.1 \%)\end{array}$ & 0.002 \\
\hline Carbohydrate foods & $\begin{array}{l}\text { Yes } \\
\text { No }\end{array}$ & $\begin{array}{l}209 \text { (31.6\%) } \\
83(12.6 \%)\end{array}$ & $\begin{array}{l}275 \text { (4I.6\%) } \\
94 \text { (14.2\%) }\end{array}$ & $\begin{array}{l}484 \text { (73.2\%) } \\
177(26.8 \%)\end{array}$ & 0.037 \\
\hline Breathing pattern & $\begin{array}{l}\text { Through the mouth } \\
\text { Through the nose } \\
\text { Both }\end{array}$ & $\begin{array}{l}126(19.1 \%) \\
124(18.8 \%) \\
42(6.4 \%)\end{array}$ & $\begin{array}{l}89(13.5 \%) \\
173(26.2 \%) \\
107(16.2 \%)\end{array}$ & $\begin{array}{l}215(32.5 \%) \\
297(44.9 \%) \\
149(22.6 \%)\end{array}$ & 0.000 \\
\hline Smoking history & $\begin{array}{l}\text { Yes } \\
\text { No }\end{array}$ & $\begin{array}{l}28(4.2 \%) \\
264(39.94)\end{array}$ & $\begin{array}{l}14(2.1 \%) \\
355(53.7)\end{array}$ & $\begin{array}{l}42(6.4 \%) \\
619(93.6)\end{array}$ & 0.008 \\
\hline Systemic disease & $\begin{array}{l}\text { Yes } \\
\text { No }\end{array}$ & $\begin{array}{l}40(6.1 \%) \\
252(38.1 \%)\end{array}$ & $\begin{array}{l}21(3.2 \%) \\
348(52.6 \%)\end{array}$ & $\begin{array}{l}6 \mathrm{I}(9.2 \%) \\
600(90.8 \%)\end{array}$ & 0.000 \\
\hline Periodontal disease & $\begin{array}{l}\text { Yes } \\
\text { No }\end{array}$ & $\begin{array}{l}68(10.3 \%) \\
224(33.9 \%)\end{array}$ & $\begin{array}{l}0(0.0 \%) \\
369(55.8 \%)\end{array}$ & $\begin{array}{l}68(10.3 \%) \\
593(89.7 \%)\end{array}$ & 0.001 \\
\hline Dental caries & $\begin{array}{l}\text { Yes } \\
\text { No }\end{array}$ & $\begin{array}{l}\text { I } 22 \text { (I8.5\%) } \\
\text { I70 (25.7\%) }\end{array}$ & $\begin{array}{l}28(4.2 \%) \\
34 I(51.6 \%)\end{array}$ & $\begin{array}{l}\text { I50 (22.7\%) } \\
51 \mid(77.3 \%)\end{array}$ & 0.000 \\
\hline Malocclusion & $\begin{array}{l}\text { Yes } \\
\text { No }\end{array}$ & $\begin{array}{l}35(5.3 \%) \\
257(38.9 \%)\end{array}$ & $\begin{array}{l}0(0.0 \%) \\
369(55.8 \%)\end{array}$ & $\begin{array}{l}35(5.3 \%) \\
626(94.7 \%)\end{array}$ & 0.007 \\
\hline
\end{tabular}


model as independent variables for the outcome of halitosis. The analysis showed that residency, monthly income, tooth-brushing habits, smoking, and dental caries were identified as independently associated with halitosis (Table 3).

\section{Discussion}

The prevalence of halitosis was found to be $44.2 \%$ ( $95 \%$ CI: 40.39-0.4796) which is consistent with a study done in Saudi Arabia (42.1\%). ${ }^{27}$ However, this result is higher than a study done in Kuwait $(23.3 \%)^{29}$ and lower compared with studies done in Pakistan $(75.1 \%)^{30}$ and Brazil
$(63 \%){ }^{31}$ The difference might be due to variation in the study population and socio-demographic variation between the countries.

The present study found that oral halitosis was high in smokers where smokers were 2.69 times at risk of developing halitosis than nonsmokers $(\mathrm{AOR}=2.69,95 \% \mathrm{CI}$ : 1.39 , 5.21) which is consistent with previous studies. ${ }^{29,33,34}$ This might be due to some volatile compounds in cigarettes. ${ }^{35}$ Furthermore, participants with dental caries were 8.74 times more likely to develop halitosis than non-carious patients which is similar to a study done in Brazil (AOR $=3.8,95 \%$ CI: 1.6-9.2) ${ }^{36}$ The high prevalence of halitosis might be due

Table 3 Logistic Regression Analysis to Show the Relation Between Halitosis and Associated Factors Among Participants Involved in the Study

\begin{tabular}{|c|c|c|c|c|}
\hline \multicolumn{2}{|l|}{ Variables } & \multicolumn{2}{|c|}{ Halitosis } & \multirow[t]{2}{*}{ AOR } \\
\hline & & Yes & No & \\
\hline Marital status & $\begin{array}{c}\text { Single } \\
\text { Married } \\
\text { Divorced }\end{array}$ & $\begin{array}{c}137(20.7 \%) \\
149(22.5 \%) \\
6(0.9 \%)\end{array}$ & $\begin{array}{c}I 70(25.7 \%) \\
\mid 78(26.9 \%) \\
2 \mid(3.2 \%)\end{array}$ & $\begin{array}{c}2.88(0.84,9.03) \\
4.4 I(2.16,17.10) \\
I\end{array}$ \\
\hline Educational status & $\begin{array}{c}\text { Illiterate } \\
\text { I-4 } \\
5-8 \\
9-12 \\
\text { College/University }\end{array}$ & $\begin{array}{l}90(13.6 \%) \\
44(6.7 \%) \\
42(6.4 \%) \\
28(4.2 \%) \\
88(13.3 \%)\end{array}$ & $\begin{array}{c}53(8.0 \%) \\
54(8.2 \%) \\
54(8.2 \%) \\
49(7.4 \%) \\
159(24.1 \%)\end{array}$ & $\begin{array}{c}24.72(8.95,68.29) \\
1.52(0.84,2.73) \\
1.17(0.64,2.13) \\
0.97(0.52,1.78) \\
\text { I }\end{array}$ \\
\hline Occupation & $\begin{array}{c}\text { Farmer } \\
\text { Student } \\
\text { Governmental employee } \\
\text { NGO-employee } \\
\text { Merchant/personal } \\
\text { bushiness }\end{array}$ & $\begin{array}{c}48(7.3 \%) \\
122(18.5 \%) \\
36(5.4 \%) \\
0(0.0 \%) \\
86(13.0 \%)\end{array}$ & $\begin{array}{c}50(7.6 \%) \\
112(16.9 \%) \\
83(12.6 \%) \\
15(2.3 \%) \\
109(16.5 \%)\end{array}$ & $\begin{array}{c}0.05(0.02,0.16) \\
3.12(1.71,5.68) \\
0.75(0.40,1.40) \\
0.67(0.12,1.63) \\
1\end{array}$ \\
\hline Residency & $\begin{array}{l}\text { Urban } \\
\text { Rural }\end{array}$ & $\begin{array}{l}211(31.9 \%) \\
81(12.3 \%)\end{array}$ & $\begin{array}{c}308(46.6 \%) \\
61(9.2 \%)\end{array}$ & $\begin{array}{c}\mathrm{I} \\
\mathrm{I} .94(1.33,2.82)\end{array}$ \\
\hline Monthly income & $\begin{array}{c}\leq 1000 \text { ETB } \\
1000-2500 \text { ETB } \\
\geq 250 \text { । ETB }\end{array}$ & $\begin{array}{c}147(22.2 \%) \\
92(13.9 \%) \\
53(8.0 \%)\end{array}$ & $\begin{array}{l}152(23.0 \%) \\
96(14.5 \%) \\
121(18.3 \%)\end{array}$ & $\begin{array}{c}1.81(1.06,3.09) \\
2.21(1.29,3.79) \\
I\end{array}$ \\
\hline Tooth brushing & $\begin{array}{l}\text { Yes } \\
\text { No }\end{array}$ & $\begin{array}{l}191(28.9 \%) \\
101(15.3 \%)\end{array}$ & $\begin{array}{l}287(43.4 \%) \\
82(12.4 \%)\end{array}$ & $\begin{array}{c}\mathrm{I} \\
\mathrm{I} .85(\mathrm{I} .3 \mathrm{I}, 2.6 \mathrm{I})\end{array}$ \\
\hline $\begin{array}{l}\text { Consumption of carbohydrate } \\
\text { foods }\end{array}$ & $\begin{array}{l}\text { Yes } \\
\text { No }\end{array}$ & $\begin{array}{l}209(31.6 \%) \\
83(12.6 \%)\end{array}$ & $\begin{array}{l}275(41.6 \%) \\
94(14.2 \%)\end{array}$ & $\begin{array}{c}0.86(0.6 \mathrm{I} . \mathrm{I} .22) \\
\mathrm{I}\end{array}$ \\
\hline Smoking history & $\begin{array}{l}\text { Yes } \\
\text { No }\end{array}$ & $\begin{array}{c}28(4.2 \%) \\
264(39.94)\end{array}$ & $\begin{array}{l}14(2.1 \%) \\
355(53.7)\end{array}$ & $\begin{array}{c}2.69(1.39,5.21) \\
I\end{array}$ \\
\hline Systemic disease & $\begin{array}{l}\text { Yes } \\
\text { No }\end{array}$ & $\begin{array}{c}40(6.1 \%) \\
252(38.1 \%)\end{array}$ & $\begin{array}{c}21(3.2 \%) \\
348(52.6 \%)\end{array}$ & $\begin{array}{c}1.38(0.79 .40) \\
I\end{array}$ \\
\hline Dental caries & $\begin{array}{l}\text { Yes } \\
\text { No }\end{array}$ & $\begin{array}{l}122(18.5 \%) \\
170(25.7 \%)\end{array}$ & $\begin{array}{c}28(4.2 \%) \\
34 \mid(51.6 \%)\end{array}$ & $\begin{array}{c}8.74(5.57,|13.7|) \\
\mid\end{array}$ \\
\hline
\end{tabular}


to the presence of poor oral hygiene practice and calculus accumulation in patients with dental caries.

On analysis of socioeconomic variables, a statistically significant association was found between rural residency, low monthly income, and oral halitosis. Rural residents were two times at risk of developing halitosis than urban residents (AOR $=1.94,95 \% \mathrm{CI}: 1.33,2.82)$ which corresponds with a study done in Korea. ${ }^{37}$ This might be due to low knowledge of oral health, and poor oral hygiene practice among rural residents. Besides, participants with low monthly income were 2.21 times at risk of developing halitosis (AOR=2.21, 95\% CI: 1.29,3.79) which is similar to a study done in Korea $(\mathrm{AOR}=1.85) .{ }^{37}$

Lack of oral hygiene practice, including, flossing, and use of mouthwash, has been connected to oral halitosis. In this study, participants with poor tooth brushing practice were 1.85 times at risk of affected by oral halitosis $(\mathrm{AOR}=1.85(1.31,2.61)$.

\section{Strengths and Limitations}

The present study had some limitations; first, the study did not use objective measurements of halitosis using a portable VSC detector, halimeter, or gas chromatography. Due to this, some false positives/negatives might be reported. Second, even if we used systematic random sampling participants with self-reported halitosis might exclude themselves from the study. Third, the study is a single site and hospital-based study, which will not represent the whole society of the area. The study also evaluated only oral halitosis.

\section{Conclusion}

The prevalence of oral halitosis in the study participants was $44.2 \%$. Rural residency, low monthly income, poor tooth-brushing habit, smoking, and dental caries were independent factors of halitosis.

\section{Abbreviations}

AOR, adjusted odds ratio; GERD, gastroesophageal reflux disorder; SPSS, Statistical Package for Social Sciences; VSC, volatile sulfur compounds.

\section{Data Sharing Statement}

All the data used during the analysis were no publicly available due to the agreement between the authors and the IRB of the university, but data are available from the corresponding author on reasonable request.

\section{Ethical Approval and Consent to Participate}

Ethical approval was obtained from the institutional review board of the University of Gondar. The study complied with the Declaration of Helsinki Ethical Principles for Medical Research. Written informed consent was taken from each participant and data collection was done after they signed for the consent. Moreover, informed consent was taken from parents or legal guardians for 12-18 years old.

\section{Acknowledgment}

We would thank the University of Gondar for the ethical clearance, and the dental staff for their valuable support for the project. Furthermore, we would like to acknowledge all the participants for their contribution by being part of the study.

\section{Author Contributions}

All authors made a significant contribution to the work reported, whether that is in the conception, study design, execution, acquisition of data, analysis and interpretation, or in all these areas; took part in drafting, revising or critically reviewing the article; gave final approval of the version to be published; have agreed on the journal to which the article has been submitted; and agree to be accountable for all aspects of the work.

\section{Disclosure}

The authors report no competing interests in this work.

\section{References}

1. Hughes FJ, McNab R. Oral malodour-a review. Arch Oral Biol. 2008;53(Suppl 1):S1-7.

2. Bornstein MM, Kislig K, Hoti BB, Seemann R, Lussi A. Prevalence of halitosis in the population of the city of Bern, Switzerland: a study comparing self-reported and clinical data. Eur J Oral Sci. 2009;117 (3):261-267. doi:10.1111/j.1600-0722.2009.00630.x

3. Amano A, Yoshida Y, Oho T, Koga T. Monitoring ammonia to assess halitosis. Oral Surg Oral Med Oral Pathol Oral Radiol Endodontol. 2002;94(6):692-696. doi:10.1067/moe.2002.126911

4. Van Den Velde S, Quirynen M, van Steenberghe D. Halitosis associated volatiles in breath of healthy subjects. J Chromatogr B. 2007;853(1-2):54-61. doi:10.1016/j.jchromb.2007.02.048

5. Aydin M, Harvey-Woodworth CN. Halitosis: a new definition and classification. Br Dent J. 2014;217(1):E1. doi:10.1038/sj.bdj.2014.552

6. Aydin M, Özen ME, Evlice B, Ferguson M, Uzel İ. A new measurement protocol to differentiate sources of halitosis. Acta Odontol Scand. 2016;74(5):380-384. doi:10.3109/00016357.2016.1163732

7. Iwakura M, Yasuno Y, Shimura M, Sakamoto S. Clinical characteristics of halitosis: differences in two patient groups with primary and secondary complaints of halitosis. J Dent Res. 1994;73(9):1568-1574. doi: $10.1177 / 00220345940730091301$ 
8. Bosy A. Oral malodor: philosophical and practical aspects. $J$ Can Dent Assoc. 1997;63(3):196-201.

9. ADA. Council on scientific affairs oral malodor. $J$ Am Dent Assoc 1939. 2003;134(2):209-214.

10. Azodo CC, Osazuwa-Peters N, Omili M. Psychological and social impacts of halitosis: a review. J Soc Psychol Sci. 2010;3(1):74-92.

11. Azodo CC, Onyeagba MI, Odai CD. Does concern about halitosis influence individual's oral hygiene practices? Niger Med J J Niger Med Assoc. 2011;52(4):254. doi:10.4103/0300-1652.93799

12. Domingos P, Dantas AA. A, A O. Halitosis: limiting the quality of life. Rev Odontol Univ Cid São Paulo. 2011;23:171-81.

13. Aylıkı BU, Çolak H. Halitosis: from diagnosis to management. $J$ Nat Sci Biol Med. 2013;4(1):14. doi:10.4103/0976-9668.107255

14. Porter SR, Scully C. Oral malodour (halitosis). BMJ. 2006;333 (7569):632-635. doi:10.1136/bmj.38954.631968.AE

15. Zalewska A, Zatoński M, Jab-lonka-Strom A, Paradowska A, Kawala B, Litwin A. Halitosis-a common medical and social problem. A review on pathology, diagnosis and treatment. Acta GastroEnterol Belg. 2012;75(3):300-309.

16. Kim JG, Kim YJ, Yoo SH, et al. Halimeter ppb levels as the predictor of erosive gastroesophageal reflux disease. Gut Liver. 2010;4(3):320. doi: $10.5009 / \mathrm{gnl} .2010 .4 .3 .320$

17. Lee H, Kho H-S, Chung J-W, Chung S-C, Kim Y-K. Volatile sulfur compounds produced by Helicobacter pylori. J Clin Gastroenterol. 2006;40(5):421-426. doi:10.1097/00004836-200605000-00011

18. Almas K, Al-Hawish A, Al-Khamis W. Oral hygiene practices, smoking habit, and self-perceived oral malodor among dental students. J Contemp Dent Pr. 2003;4(4):77-90. doi:10.5005/jcdp4-4-77

19. Joda AE, Olukoju OO. Halitosis amongst students in tertiary institutions in Lagos state. Afr Health Sci. 2012;12(4):473-478. doi:10.4314/ahs.v12i4.12

20. Ziaei N, Hosseinpour S, Nazari H, Rezaei M, Rezaei K. Halitosis and its associated factors among Kermanshah High school students (2015). Clin Cosmet Investig Dent. 2019;11:327. doi:10.2147/ CCIDE.S215869

21. Rosenberg M, Gelernter I, Barki M, Bar-Ness R. Day-long reduction of oral malodor by a two-phase oil: water mouthrinse as compared to chlorhexidine and placebo rinses. J Periodontol. 1992;63(1):39-43. doi:10.1902/jop.1992.63.1.39

22. De EB, De MU, Loesche WJ. Relationship between volatile sulfur compounds, BANA-hydrolyzing bacteria and gingival health in patients with and without complaints of oral malodor. J Clin Dent. 1994;4(4):114-119.

23. Hammad MM, Darwazeh AM, Al-Waeli H, Tarakji B, Alhadithy TT. Prevalence and awareness of halitosis in a sample of Jordanian population. J Int Soc Prev Community Dent. 2014;4(Suppl 3):S178. doi:10.4103/2231-0762.149033
24. Lu H-X, Tang C, Chen X, Wong MCM, Ye W. Characteristics of patients complaining of halitosis and factors associated with halitosis. Oral Dis. 2014;20(8):787-795. doi:10.1111/odi.12198

25. Quirynen M, Dadamio J, Van den Velde S, et al. Characteristics of 2000 patients who visited a halitosis clinic. J Clin Periodontol. 2009;36(11):970-975. doi:10.1111/j.1600-051X.2009.01478.x

26. Eldarrat A, Alkhabuli J, Malik A. The prevalence of self-reported halitosis and oral hygiene practices among Libyan students and office workers. Libyan J Med. 2008;3(4):170-176. doi:10.3402/ljm. v3i4.4788

27. Al-Zahrani MS, Zawawi KH, Austah ON, Al-Ghamdi HS. Self reported halitosis in relation to glycated hemoglobin level in diabetic patients. Open Dent J. 2011;5:154. doi:10.2174/ 1874210601105010154

28. Al-Ansari JM, Boodai H, Al-Sumait N, Al-Khabbaz AK, AlShammari KF, Salako N. Factors associated with self-reported halitosis in Kuwaiti patients. J Dent. 2006;34(7):444-449. doi:10.1016/j. jdent.2005.10.002

29. Nazir MA, Almas K, Majeed MI. The prevalence of halitosis (oral malodor) and associated factors among dental students and interns, Lahore, Pakistan. Eur J Dent. 2017;11(04):480-485. doi:10.4103/ejd. ejd_142_17

30. Pedrazzi V, Sato S, de Mattos M, Da GC, Lara EHG, Panzeri H. Tongue-cleaning methods: a comparative clinical trial employing a toothbrush and a tongue scraper. $J$ Periodontol. 2004;75 (7):1009-1012.

31. Liu XN, Shinada K, Chen XC, Zhang BX, Yaegaki K, Kawaguchi Y. Oral malodor-related parameters in the Chinese general population. $J \quad$ Clin Periodontol. 2006;33(1):31-36. doi:10.1111/j.1600051X.2005.00862.x

32. Bornstein MM, Stocker BL, Seemann R, Bürgin WB, Lussi A. Prevalence of halitosis in young male adults: a study in Swiss army recruits comparing self-reported and clinical data. J Periodontol. 2009;80(1):24-31. doi:10.1902/jop.2009.080310

33. McNab R. Oral malodour-a review. Arch Oral Biol. 2008;53:S1-7.

34. Guedes CC, Bussadori SK, Weber R, Motta L, Ciarcia AC, Amancio OMS. Halitosis: prevalence and association with oral etiological factors in children and adolescents. J Breath Res. 2019;13 (2):026002. doi:10.1088/1752-7163/aafc6f

35. Kim SY, Sim S, Kim S-G, Park B, Choi HG. Prevalence and associated factors of subjective halitosis in Korean adolescents. PLoS One. 2015;10:10.

36. Feller L, Blignaut E. Halitosis: a review. SADJ J South Afr Dent Assoc Tydskr Van Suid-Afr Tandheelkd Ver. 2005;60(1):17-19.

37. Pratibha PK, Bhat GS. Oral malodor: a review of the literature. $A m$ Dent Hyg Assoc. 2006;80(3):8.

Clinical, Cosmetic and Investigational Dentistry

Dovepress

\section{Publish your work in this journal}

Clinical, Cosmetic and Investigational Dentistry is an international, peer-reviewed, open access, online journal focusing on the latest clinical and experimental research in dentistry with specific emphasis on cosmetic interventions. Innovative developments in dental materials, techniques and devices that improve outcomes and patient

satisfaction and preference will be highlighted. The manuscript management system is completely online and includes a very quick and fair peer-review system, which is all easy to use. Visit

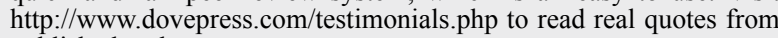
published authors. 